\title{
High amplification of FGFR1 gene is a delayed poor prognostic factor in early stage ESCC patients
}

\author{
Qi Song ${ }^{1, *}$, Yalan Liu ${ }^{1, *}$, Dongxian Jiang ${ }^{1}$, Haixing Wang ${ }^{1}$, Jie Huang ${ }^{1}$, Yifan $X \mathbf{u}^{1}$, \\ Akesu Sujie ${ }^{1}$, Haiying Zeng ${ }^{1}$, Chen $\mathrm{Xu}^{1}$ and Yingyong $\mathrm{Hou}^{1,2}$ \\ ${ }^{1}$ Department of Pathology, Zhongshan Hospital, Fudan University, Shanghai 200032, P. R. China \\ ${ }^{2}$ Department of Pathology, School of Basic Medical Sciences \& Zhongshan Hospital, Fudan University, Shanghai 200032, P. \\ R. China \\ "These authors have contributed equally to this work \\ Correspondence to: Yingyong Hou, email: houyingyong@aliyun.com \\ Chen Xu, email: Xu.chen@zs-hospital.sh.cn \\ Keywords: FGFRI high amplification, clinical stage, disease free survival time, prognostic marker, ESCC \\ Received: October 17, $2016 \quad$ Accepted: June 29, $2017 \quad$ Published: August 12, 2017 \\ Copyright: Song et al. This is an open-access article distributed under the terms of the Creative Commons Attribution License 3.0 \\ (CC BY 3.0), which permits unrestricted use, distribution, and reproduction in any medium, provided the original author and source \\ are credited.
}

\section{ABSTRACT}

Amplification of the fibroblast growth factor receptor 1 (FGFR1) is believed to predict response to FGFR inhibitors. The aim of this study was to investigate the frequency and the prognostic impact of FGFR1 amplification in patients with resected esophageal squamous cell carcinoma (ESCC) by using fluorescent in situ hybridization. Microarrayed paraffin embedded blocks were constructed, and the cohort of tissues came from 506 patients with ESCC. FGFR1 high amplification (FGFR1 ${ }^{\text {high }}$ ) was defined by an FGFR1/centromere 8 ratio of $\geq 2.0$, or average number of FGFR1 signals/tumor cell nucleus $\geq 6.0$, or percentage of tumor cells containing $\geq 15$ FGFR1 signals, or large cluster in $\geq 10 \%$ of cancer cells. FGFR1 low amplification was defined by $\geq 5$ FGFR1 signals in $\geq \mathbf{5 0} \%$ of cancer cells. Kaplan-Meier curves with log-rank tests and Cox proportional hazards model were used to analyze patients' survival. Among 506

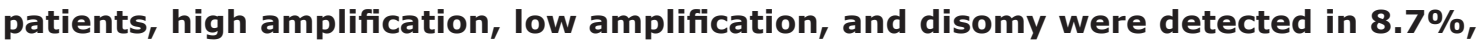
$3.6 \%$ and $87.7 \%$, respectively. In general, the FGFR1 ${ }^{\text {high }}$ group trended towards worse disease-free survival (DFS) and overall survival (OS) compared to the FGFR1 low amplification/disomy (FGFR1 ${ }^{\text {low/disomy }}$ ) group (DFS, $P=0.108 ; 0 S, P=0.112$ ), but this trend was amplified for patients with DFS $\geq 30$ months (DFS, $P=0.009 ; 0 S, P=0.007$ ). Furthermore, when patients were stratified into stage I-II and stage III-IV, the FGFR1 ${ }^{\text {high }}$ group directly presented with adverse DFS and OS than the FGFR1 ${ }^{\text {low/disomy }}$ group in stage I-II patients ( $D F S, P=0.019 ; 0 S, P=0.034$ ), especially with DFS $\geq 30$ months (DFS, $P=0.002$; OS, $P=0.001$ ). However, for patients in stage III-IV, FGFR1 ${ }^{\text {high }}$ had no effect on prognosis regardless of DFS time. FGFR1 ${ }^{\text {high }}$ occurs in a minority of ESCC, and it predicts delayed poor prognosis in stage I and II ESCC patients.

\section{INTRODUCTION}

Esophageal cancer (EC) is the sixth leading cause of cancer-related mortality worldwide resulting in more than 400,000 deaths annually [1]. A lack of effective chemotherapeutic approaches available to treat patients with EC combined with the fact that many EC patients are diagnosed at advanced stages both contribute to the poor prognosis of this disease [2]. Based on histologic criteria, EC is separated into two major types: esophageal squamous cell cancer (ESCC) and esophageal adenocarcinoma (EAC). ESCC accounts for approximately $90 \%$ of EC worldwide [3], which is the main subtype in China and ESCC is the third most commonly diagnosed cancer among men, while the fifth among women [4]. 
In recent years, studies that comprehensively characterized the genomic landscape of ESCC and EAC have led to an important understanding of the genetic basis of EC and identified genes associated with the pathogenesis of the specific EC subtypes [5-9]. EAC and ESCC represent distinct disease entities, which may benefit from different therapeutic strategies. Despite advances in personalized treatment of EAC $[10,11]$, effective targeted therapies for ESCC have remained elusive. Fibroblast growth factor receptor 1 (FGFR1) amplification is one of the most promising findings in ESCC genomic studies due to the availability of FGFR inhibitors and its association with response to FGFR inhibitor treatment $[12,13]$.

The FGFR tyrosine kinase family consists four kinases: FGFR1, FGFR2, FGFR3, and FGFR4 and the ligands comprise 22 family members (fibroblast growth factors, FGFs). FGFRs share structural homology with many pharmacologic therapeutic targets, such as vascular endothelial growth factor receptors (VEGFRs) and plateletderived growth factor receptors (PDGFRs) [14]. Receptor activation by FGFs initiates a series of intracellular events that activates major survival and proliferative signal pathways, and then regulate many biologic processes including the wound repair, formation of new blood vessels, and embryonic development [15]. More recently, increasing evidence demonstrated that FGFRs play crucial roles in cancer development. FGFRs are deregulated by amplification, point mutation, or translocation and amplification is the most common deregulation form in multiple cancer types [16-18]. Amplification of FGFR1 has been reported in 13\%-22\% squamous cell lung cancer $[13,19,20], 20 \%$ breast cancer $[12,21], 10 \%-17 \%$ head and neck squamous cell carcinoma $[22,23]$, and $26.9 \%$ malignant peripheral nerve sheath tumor [24]. FGFR1 amplification induced a strong FGFR1 dependency that could be exploited therapeutically, and in vivo studies have demonstrated inhibition of the FGFRl pathway with FGFR inhibitors that led to significant tumor shrinkage $[13,25]$, and translational clinical trials are undertaken [26].

As the significant clinical value of FGFR1, the prevalence and the prognostic value of FGFR 1 amplification in ESCC is urgently needed to explore. Some researchers have reported that $F G F R 1$ amplification rate, ranging from $6 \%$ to $9.7 \%$ [27-29]. However, the prognostic value of FGFR1 amplification is not consistent in different studies. Kim et al [27] recently reported high FGFRl amplification is an independent poor prognostic factor and a potential therapeutic target in ESCC. In another study [28] on Caucasian patients, there was no association between FGFRl amplification status and clinical outcome. Therefore, further detailed analysis is needed to investigate the prognostic significance of FGFRI amplification in ESCC.

In present study, we analyzed FGFR1 amplification status in 506 ESCC patients with surgically resected and searched for correlations between FGFRl amplification and clinicopathological parameters. We meticulously explored the prognostic value of FGFR1 amplification in these patients with the purpose of precisely predicting patients' outcome.

\section{RESULTS}

\section{Patient characteristics}

A total of 506 ESCC patients who underwent curative esophagectomy were enrolled (Figure 1) in our analysis and the clinical characteristics were listed in Table 1. There were 415 males and 91 females with a median age of 61.2 years (range 34-83). By anatomic site, 29 were in the upper esophagus, 238 in the middle and 239 in the lower area. A total of 111 tumors had invaded to the mucous layer or submucosa, 224 to the muscularis propria and 171 to the adventitia. Most of the tumor differentiation was grade II (55.7\%), 40.1\% was grade III, and only $4.2 \%$ was grade I. A total of 183 tumors were examined with nerve infiltration, 110 with vessel involvement, 244 with lymph node metastases, and 59 with distant metastases.

\section{FGFR1 amplification status and clinicopathological features}

Based on a previous study [30], patients were classified into three groups by using prespecified criteria for the FGFR1 gene copy number and FGFR1/ centromere 8 (CEN8) ratio. Among a total of 506 patients, 44 (8.7\%) were high FGFRl amplification, 18 (3.6\%) were low FGFR1 amplification, and $444(87.7 \%)$ were disomy (Figure 2; Table 1). The median FGFR1 gene copy number per nucleus and the mean FGFR1/CEN8 ratio in all patients were 2.45 (range, 0 to 12.25 copies per nucleus) and 1.21 (range, 0 to 4.64). The median FGFR1 gene copy number was 6.57 (range, 3.19 to 12.25 ) in high amplification, 3.91 (range, 3.33 to 5.92) in low amplification, and 1.98 (range 0 to 4.20 ) in disomy group. The mean FGFR1/ CEN8 ratio was 3.75 (range 0.89 to 4.64 ), 1.49 (range, 1.12 to 1.90 ), and 0.95 (range, 0 to 1.75 ) in high, low and disomy group, respectively. Of 44 high $F G F R 1$ amplified tumors, 5 cases (11.4\%) only satisfied the criterion of FGFR1/ CEN8 ratio is $\geq 2.0,7$ cases $(15.9 \%)$ only satisfied the criterion of an average number of FGFR1 signal per nucleus $\geq 6.0$, and 26 cases $(59.1 \%)$ only satisfied the criterion of percentage of tumor cells containing $\geq 15$ FGFRl signals or large clusters in $\geq 10 \%$ cells. And only one case $(2.3 \%)$ satisfied the criteria of $F G F R 1 / \mathrm{CEN} 8$ ratio is $\geq 2.0$ and an average number of $F G F R 1$ signal per nucleus $\geq 6.0$. Five cases (11.4\%) satisfied all three criteria for FGFR1 amplification.

Associations between FGFR1 amplification and clinicopathological characteristics for the 506 patients were shown in Table 2. FGFR1 amplification status correlated with clinical stage $(P=0.047)$, lymph node metastasis $(P=0.032)$, and necrosis $(P=0.008)$. And high FGFR1 amplification is positively correlated with advanced stage, positive lymph node metastasis, and 
Table 1: Clinicopathological characteristics of the 506 patients with ESCC

\begin{tabular}{|c|c|c|c|c|c|c|c|c|}
\hline \multirow[t]{2}{*}{ Characteristics } & \multicolumn{2}{|c|}{ All patients } & \multicolumn{2}{|c|}{$\begin{array}{l}\text { Patients with Stage } \\
\text { I-II disease }\end{array}$} & \multicolumn{2}{|c|}{$\begin{array}{l}\text { Patients with DFS } \\
\text { time } \geq 30 \text { months }\end{array}$} & \multicolumn{2}{|c|}{$\begin{array}{c}\text { Patients with DFS } \\
\text { time } \geq \mathbf{3 0 m o n t h s ~ i n ~ s t a g e ~ I - I I ~}\end{array}$} \\
\hline & No. & $\%$ & No. & $\%$ & No. & $\%$ & No. & $\%$ \\
\hline Total & 506 & 100.0 & 301 & 100.0 & 259 & 100.0 & 201 & 100.0 \\
\hline \multicolumn{9}{|l|}{ Gender } \\
\hline Male & 415 & 82.0 & 236 & 78.4 & 205 & 79.2 & 154 & 76.6 \\
\hline Female & 91 & 18.0 & 65 & 21.6 & 54 & 20.8 & 47 & 23.4 \\
\hline \multicolumn{9}{|l|}{ Age } \\
\hline$<60$ & 215 & 42.5 & 121 & 40.2 & 117 & 45.2 & 89 & 44.3 \\
\hline$\geq 60$ & 291 & 57.5 & 180 & 59.8 & 142 & 54.8 & 112 & 55.7 \\
\hline \multicolumn{9}{|l|}{ Tumor site } \\
\hline Upper & 29 & 5.7 & 20 & 6.6 & 15 & 5.8 & 14 & 7.0 \\
\hline Middle & 238 & 47.0 & 158 & 52.5 & 124 & 47.9 & 106 & 52.7 \\
\hline Low & 239 & 47.2 & 123 & 40.9 & 120 & 46.3 & 81 & 40.3 \\
\hline \multicolumn{9}{|l|}{ Differentiation } \\
\hline Well & 21 & 4.2 & 15 & 5.0 & 13 & 5.0 & 12 & 6.0 \\
\hline Moderate & 282 & 55.7 & 182 & 60.5 & 149 & 57.5 & 123 & 61.2 \\
\hline Poor & 203 & 40.1 & 104 & 34.6 & 97 & 37.5 & 66 & 32.8 \\
\hline \multicolumn{9}{|l|}{ Clinical stage } \\
\hline $\mathrm{I}+\mathrm{II}$ & 301 & 59.5 & & & 201 & 77.6 & & \\
\hline III+IV & 205 & 40.5 & & & 58 & 22.4 & & \\
\hline \multicolumn{9}{|l|}{ Invasive depth } \\
\hline I & 111 & 21.9 & 106 & 35.2 & 76 & 29.3 & 73 & 36.3 \\
\hline II & 224 & 44.3 & 126 & 41.9 & 104 & 40.2 & 84 & 41.8 \\
\hline III & 171 & 33.8 & 69 & 22.9 & 79 & 30.5 & 44 & 21.9 \\
\hline \multicolumn{9}{|l|}{$\begin{array}{l}\text { Lymph node } \\
\text { metastasis }\end{array}$} \\
\hline No & 262 & 51.8 & 250 & 83.1 & 178 & 68.7 & 177 & 88.1 \\
\hline Yes & 244 & 48.2 & 51 & 16.9 & 81 & 31.3 & 24 & 11.9 \\
\hline \multicolumn{9}{|l|}{ Distant metastasis } \\
\hline No & 447 & 88.3 & 275 & 91.4 & 249 & 96.1 & 196 & 97.5 \\
\hline Yes & 59 & 11.7 & 26 & 8.6 & 10 & 3.9 & 5 & 2.5 \\
\hline \multicolumn{9}{|c|}{ Vessel involvement } \\
\hline No & 396 & 78.3 & 268 & 89.0 & 209 & 80.7 & 177 & 88.1 \\
\hline Yes & 110 & 21.7 & 33 & 11.0 & 50 & 19.3 & 24 & 11.9 \\
\hline \multicolumn{9}{|c|}{ Nerve involvement } \\
\hline No & 323 & 63.8 & 226 & 75.1 & 183 & 70.7 & 152 & 75.6 \\
\hline Yes & 183 & 36.2 & 75 & 24.9 & 76 & 29.3 & 49 & $\begin{array}{l}24.4 \\
\text { (Continued) }\end{array}$ \\
\hline
\end{tabular}




\begin{tabular}{|c|c|c|c|c|c|c|c|c|}
\hline \multirow[t]{2}{*}{ Characteristics } & \multicolumn{2}{|c|}{ All patients } & \multicolumn{2}{|c|}{$\begin{array}{l}\text { Patients with Stage } \\
\text { I-II disease }\end{array}$} & \multicolumn{2}{|c|}{$\begin{array}{c}\text { Patients with DFS } \\
\text { time } \geq 30 \text { months }\end{array}$} & \multicolumn{2}{|c|}{$\begin{array}{c}\text { Patients with DFS } \\
\text { time } \geq 30 \text { months in stage I-II }\end{array}$} \\
\hline & No. & $\%$ & No. & $\%$ & No. & $\%$ & No. & $\%$ \\
\hline \multicolumn{9}{|l|}{ Necrosis } \\
\hline No & 353 & 69.8 & 225 & 74.8 & 185 & 71.4 & 152 & 75.6 \\
\hline Yes & 153 & 30.2 & 76 & 25.2 & 74 & 28.6 & 49 & 24.4 \\
\hline \multicolumn{9}{|l|}{ Smoking } \\
\hline No & 309 & 61.1 & 202 & 67.1 & 165 & 63.7 & 136 & 67.7 \\
\hline Yes & 197 & 38.9 & 99 & 32.9 & 94 & 36.3 & 65 & 32.3 \\
\hline \multicolumn{9}{|l|}{$\begin{array}{l}\text { FGFR1 } \\
\text { amplification }\end{array}$} \\
\hline High & 44 & 8.7 & 20 & 6.6 & 20 & 7.7 & 10 & 5.0 \\
\hline Low & 18 & 3.6 & 8 & 2.7 & 9 & 3.5 & 7 & 3.5 \\
\hline Disomy & 444 & 87.7 & 273 & 90.7 & 230 & 88.8 & 184 & 91.5 \\
\hline
\end{tabular}

Invasive depth I, tumors had invaded to the mucous layer or submucosa; II, to the muscularis propria; III, to or beyond the adventitia.

necrosis. There was no significant difference between the FGFR $1^{\text {high }}$ and FGFR $1^{\text {low/lisomy }}$ group regarding gender, age, tumor site, invasive depth, distant metastasis, differentiation, vessel involvement, nerve involvement, and smoking.

\section{Survival outcomes in the cohort of ESCC patients}

With a median follow-up time of 35 months (range 2-102 months), the 5-year DFS and OS rate for all patients

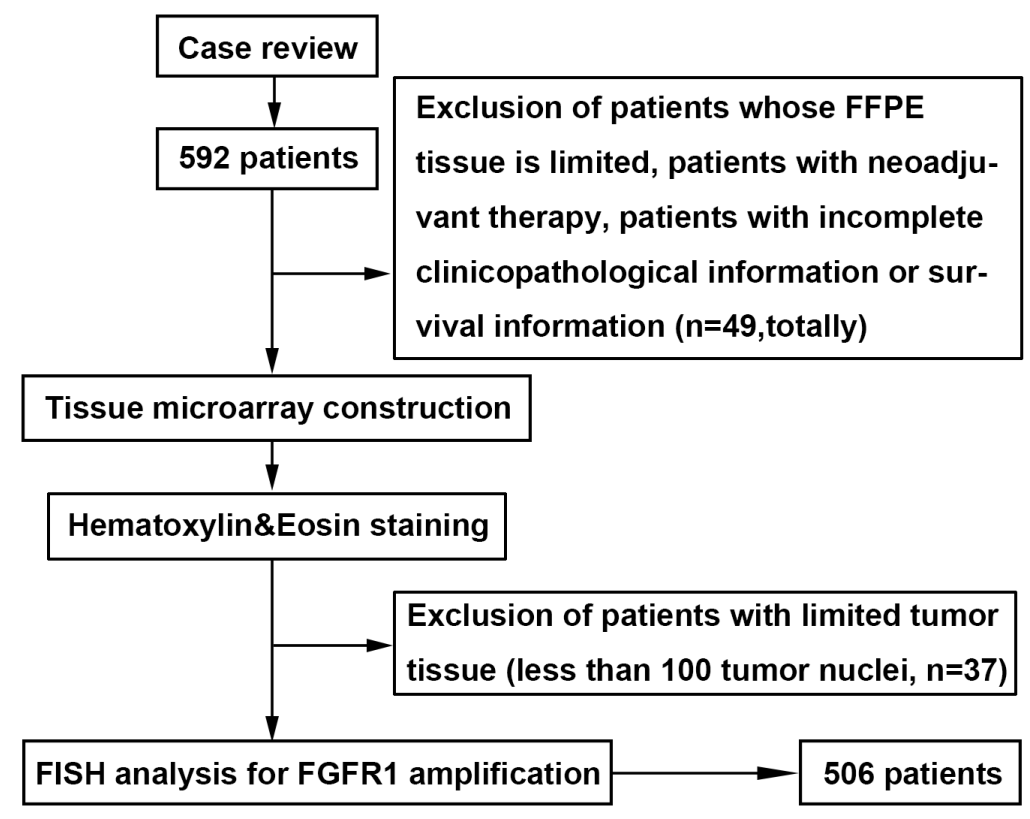

Figure 1: Patients and sample selection flow chart. Cases with ESCC were identified retrospectively and re-reviewed. Patients whose paraffin-embedded tissue is limited, patients with neoadjuvant therapy, and those with incomplete clinicopathological information or survival information were excluded. Representative tissue blocks were selected, Tissue microarray (TMA) construction was undertaken, and hematoxylin-eosin staining was performed. Patients with limited tumor tissue (less than 100 tumor nuclei) in TMA were excluded. Fluorescent in situ hybridization for FGFR1 was undertaken. The final cohort of ESCC patients consisted of 506 cases. 
Table 2: Association between FGFR1-FISH results and the clinicopathlolgical characteristics in the cohort of 506 ESCC patients.

\begin{tabular}{|c|c|c|c|c|c|}
\hline \multirow{3}{*}{ Characteristics } & \multicolumn{4}{|c|}{ FGFR1-FISH results } & \multirow{3}{*}{$\mathbf{P}$} \\
\hline & \multicolumn{2}{|c|}{ High amplification } & \multicolumn{2}{|c|}{ Low amplification/Disomy } & \\
\hline & No. & $\%$ & No. & $\%$ & \\
\hline Total & 44 & 8.7 & 462 & 91.3 & \\
\hline Gender & & & & & 0.432 \\
\hline Male & 38 & 9.2 & 377 & 90.8 & \\
\hline Female & 6 & 6.6 & 85 & 93.4 & \\
\hline Age & & & & & 0.677 \\
\hline$<60$ & 20 & 9.3 & 195 & 90.7 & \\
\hline$\geq 60$ & 24 & 8.2 & 267 & 91.8 & \\
\hline Tumor site & & & & & 0.939 \\
\hline Upper & 2 & 6.9 & 27 & 93.1 & \\
\hline Middle & 21 & 8.8 & 217 & 91.2 & \\
\hline Low & 21 & 8.8 & 218 & 91.2 & \\
\hline Differentiation & & & & & 0.178 \\
\hline Well & 0 & 0 & 21 & 100.0 & \\
\hline Moderate & 22 & 7.8 & 260 & 92.2 & \\
\hline Poor & 22 & 10.8 & 181 & 89.2 & \\
\hline Clinical stage & & & & & $0.047 *$ \\
\hline $\mathrm{I}+\mathrm{II}$ & 20 & 6.6 & 281 & 93.4 & \\
\hline $\mathrm{III}+\mathrm{IV}$ & 24 & 11.7 & 181 & 88.3 & \\
\hline Invasive depth & & & & & 0.167 \\
\hline I & 6 & 5.4 & 105 & 94.6 & \\
\hline II & 18 & 8.0 & 206 & 92.0 & \\
\hline III & 20 & 11.7 & 151 & 88.3 & \\
\hline Lymph node metastasis & & & & & $0.032 *$ \\
\hline No & 16 & 6.1 & 246 & 93.9 & \\
\hline Yes & 28 & 11.5 & 216 & 88.5 & \\
\hline Distant metastasis & & & & & 0.358 \\
\hline No & 37 & 8.3 & 410 & 91.7 & \\
\hline Yes & 7 & 11.9 & 52 & 88.1 & \\
\hline Vessel involvement & & & & & 0.352 \\
\hline No & 32 & 8.1 & 364 & 91.9 & \\
\hline Yes & 12 & 10.9 & 98 & 89.1 & \\
\hline Nerve involvement & & & & & 0.180 \\
\hline No & 24 & 7.4 & 299 & 92.6 & \\
\hline Yes & 20 & 10.9 & 163 & 89.1 & \\
\hline
\end{tabular}




\begin{tabular}{lccccc}
\hline \multirow{2}{*}{ Characteristics } & \multicolumn{5}{c}{ FGFR1-FISH results } \\
\cline { 2 - 3 } & \multicolumn{2}{c}{ High amplification } & & Low amplification/Disomy & P \\
\cline { 2 - 3 } \cline { 5 - 6 } & No. & \% & & No. & $0.008^{*}$ \\
\hline Necrosis & 23 & 6.5 & 330 & 93.5 & \\
No & 21 & 13.7 & 132 & 86.3 & 0.491 \\
Yes & & & & & \\
Smoking & 29 & 9.4 & 280 & 90.6 & 92.4 \\
No & 15 & 7.6 & 182 & &
\end{tabular}

Invasive depth I, tumors had invaded to the mucous layer or submucosa; II, to the muscularis propria; III, to or beyond the adventitia.

*P-value derived from $\chi 2$ test.

were $44.6 \%$ and $45 \%$. Mean and median times to DFS were 55.5 and 36.0 months. Mean and median times to OS were 59.2 and 42.0 months. The 5-year DFS rate according to clinical stages were $60.9 \%$ in stage I-II, and $20.3 \%$ in stage III-IV patients. The 5 -year OS rate was $61.1 \%$ for stage I-II, and $21.0 \%$ for stage III-IV patients.

Kaplan-Meier curves with a log rank test for DFS and OS were undertaken to assess the possible association between ESCC FGFR1 amplification and patient survival. As shown in Figure 3A and 3B, the estimated mean DFS times and OS times were not significantly different in three FGFRI groups, which was consistent with a previous report [27]. As the low amplification group has a better DFS and OS trend (DFS, $P=0.118$; OS, $P=0.122$ ) than $F G F R I^{\text {high }}$ group and has no statistical difference (DFS, $P=0.521$; OS, $P=0.504$ ) with the disomy group, we categorized total patients into $F G F R l^{\text {high }}$ group and FGFR $1^{\text {lowdisomy }}$ group. Then we assessed the survival outcomes of these two groups, $F G F R 1^{\text {high }}$ group did not represent a statistically significant adverse prognosis than FGFR $1^{\text {low/disomy }}$ group, which is different from the former research [24] (Figure 3C and 3D).

The result of univariate analysis revealed that both DFS and OS were significantly associated with clinical stage $(P<0.001)$, lymph node metastasis $(P<0.001)$, distant metastasis $(P<0.001)$, vessel involvement $(P=0.002)$, and nerve involvement (DFS, $P=0.002$; OS, $P<0.001$ ). Upon multivariate analysis, both DFS and OS were associated with clinical stage (DFS, $P=0.001$; OS, $P=0.003$ ), lymph node metastasis (DFS, $P=0.013$; OS, $P=0.009$ ), and distant metastasis $(P<0.001)$. However, no matter in univariate or multivariate analysis, FGFR1 amplification status is not a prognostic factor concerning to DFS and OS (Supplementary Table 1).

\section{Survival outcomes based on clinical stage}

To the stage I-II group, the estimated mean DFS time of the FGFRI $I^{\text {high }}$ group was significantly
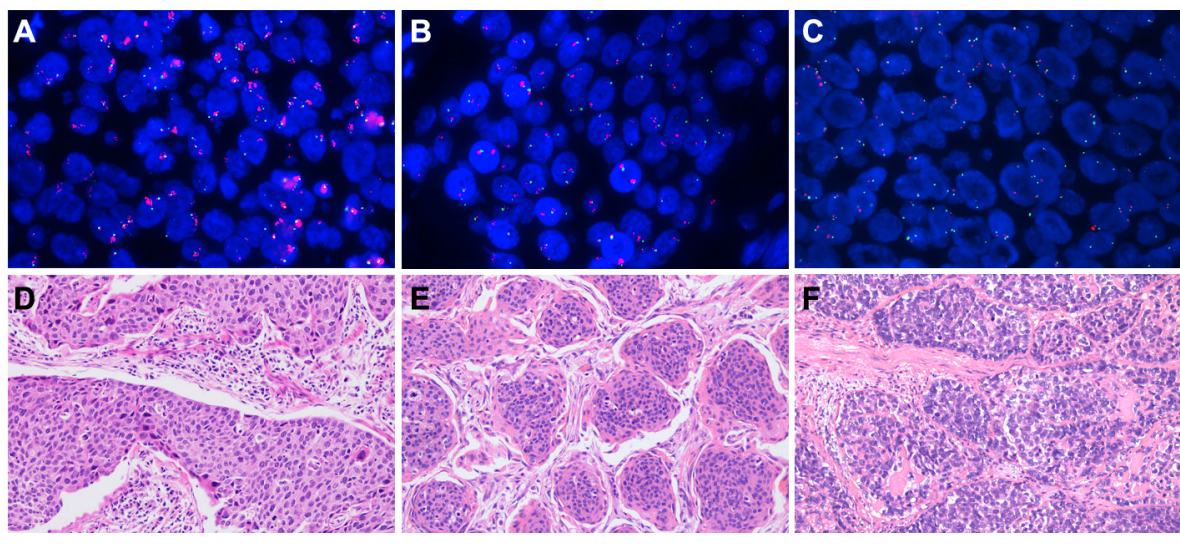

Figure 2: Fibroblast growth factor receptor 1 (FGFR1) amplification assessed by fluorescent in situ hybridization and the corresponding hematoxylin-eosin (HE) staining. The $F G F R 1$ gene was labeled in red and the CEN8 reference probe in green. (A) high FGFR1 amplification; (B) low FGFR1 amplification; (C) disomy; (D) the corresponding HE staining of high FGFR1 amplification; (E) the corresponding HE staining of low FGFRl amplification; (F) the corresponding HE staining of disomy. 
shorter compared with that of the FGFR $1^{\text {low/disomy }}$ group (41.35 \pm 6.58 and $71.45 \pm 2.42 P=0.019$, Figure 3E). Meanwhile, the estimated mean OS time was 47.59 \pm 5.56 and 74.10 \pm 2.27 months for patients with FGFR $1^{\text {high }}$ and FGFR $1^{\text {low/disomy }}$ tumors $(P=0.034$, Figure $3 \mathrm{~F})$. As to the stage III-IV patients, 5-year DFS and OS rate had no significant difference between FGFR $1^{\text {high }}$ and FGFR $1^{\text {low }}$ disomy group. Conversely, FGFR $1^{\text {high }}$ group showed a little better survival rate than $F G F R 1^{\text {low/disomy }}$ group (Figure $3 \mathrm{G}$ and $3 \mathrm{~F})$.

The univariate analysis revealed that patients with FGFR $1^{\text {high }}$ had a significantly adverse DFS and OS rate (DFS, $P=0.023$; OS, $P=0.039$ ) than patients with FGFR $1^{\text {low/disomy }}$ in stage I-II patients other than in stage III-IV patients. In addition, both DFS and OS were significantly associated with lymph node metastasis $(P<0.001)$ and distant metastasis $(P<0.001)$ in stage I-II patients and III-IV patients (Table 3 and Supplementary Table 2). However, the multivariate analysis revealed that the FGFR $1^{\text {high }}$ is not a significant independent adverse factor for DFS and OS in stage I-II patients and III-IV patients (Table 3 and Supplementary Table 2).

\section{Survival outcomes based on DFS time}

As DFS time is a valuable parameter in evaluating patients' health status after surgery and the impact of FGFR1 amplification to DFS and OS showed a delayed trend, so we divided the whole cohort of ESCC patients into two groups according to different DFS times $(24,26$, 28,30 , and 32 month respectively). After calculating these five different dividing months, we found that 30-month was the best dividing cutoff value (Supplementary Table 3 ). Therefore, the cohort of ESCC patients were divided into DFS $<30$ months group and DFS $\geq 30$ months group.

The estimated mean DFS time of the FGFR $1^{\text {high }}$ patients was significantly shorter compared with that of the FGFR $1^{\text {low/disomy }}$ patients in $\mathrm{DFS} \geq 30$ months group (72.80 \pm 6.90 and $91.74 \pm 1.58$ months $P=0.009$, Figure $3 \mathrm{~K})$. In addition, the estimated mean OS time was $74.36 \pm 6.31$
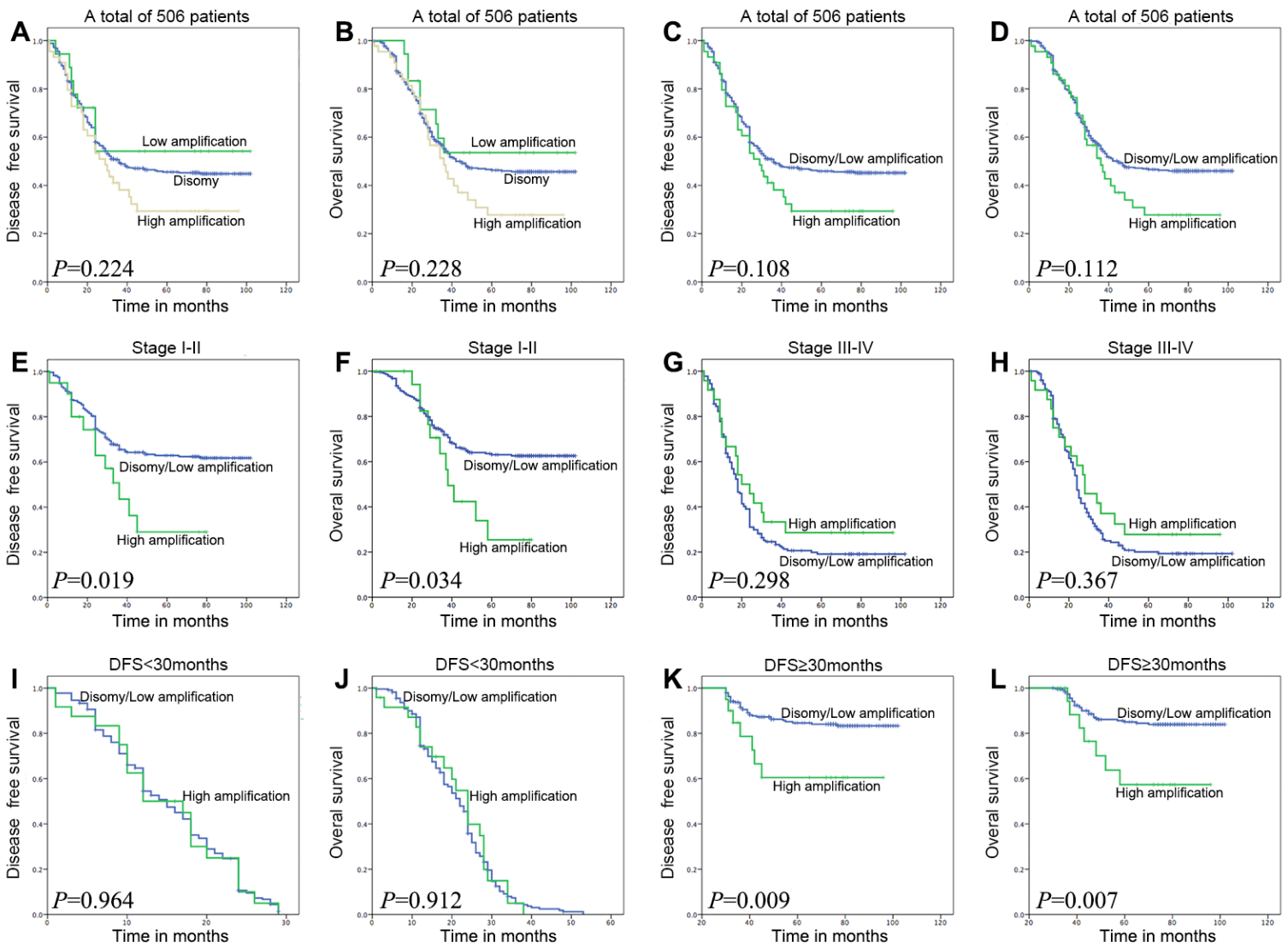

Figure 3: Survival analysis on the cohort of ESCC patients, on the basis of clinical stage, and on the basis of DFS time 30 months as a group-dividing value. To the whole cohort of patients, the FGFR1 amplification status has no correlation with DFS and OS time no matter in three groups or in two groups (A, B, C, and D). In patients with stage I-II, FGFR $1^{\text {high }}$ was associated with adverse DFS and OS (E and F; $P=0.019$ or 0.034$)$. In DFS $\geq 30$ months group, $F G F R l^{\text {high }}$ did represent poor DFS and OS (K and $\mathbf{L} ; P=0.009$ or 0.007). However, in patients with stage III-IV disease or DFS $<30$ months group, high FGFRI amplification was not associated with DFS and $\mathrm{OS}(\mathbf{G}, \mathbf{H}, \mathbf{I}$ and $\mathbf{J} ; P=0.298,0.367,0.964$ or 0.912$)$. 
Table 3: Association between clinicopathological characteristics and DFS/OS by COX regression model analysis in ESCC patients with stage I and II disease.

\begin{tabular}{|c|c|c|c|c|c|c|c|c|c|c|c|c|}
\hline & \multicolumn{6}{|c|}{ DFS } & \multicolumn{6}{|c|}{ OS } \\
\hline & \multicolumn{3}{|c|}{ Univariate } & \multicolumn{3}{|c|}{ Multivariate } & \multicolumn{3}{|c|}{ Univariate } & \multicolumn{3}{|c|}{ Multivariate } \\
\hline & HR & CI (95\%) & P value & HR & CI (95\%) & P value & HR & CI (95\%) & Pvalue & HR & CI (95\%) & P value \\
\hline \multicolumn{13}{|l|}{ Gender } \\
\hline Male & 1 & & & 1 & & & 1 & & & 1 & & \\
\hline Female & 0.964 & $0.622-1.492$ & 0.868 & 1.190 & $0.762-1.861$ & 0.445 & 0.982 & $0.629-1.534$ & 0.936 & 1.214 & $0.770-1.913$ & 0.403 \\
\hline \multicolumn{13}{|l|}{ Age } \\
\hline$<60$ & 1 & & & & & & 1 & & & & & \\
\hline$\geq 60$ & 1.068 & $0.735-1.551$ & 0.729 & & & & 1.047 & $0.715-1.531$ & 0.814 & & & \\
\hline \multicolumn{13}{|l|}{ Tumor site } \\
\hline Upper/middle & 1 & & & & & & 1 & & & & & \\
\hline Low & 0.920 & $0.631-1.340$ & 0.663 & & & & 0.930 & $0.632-1.369$ & 0.712 & & & \\
\hline \multicolumn{13}{|l|}{ Smoking } \\
\hline No & 1 & & & & & & 1 & & & & & \\
\hline Yes & 0.944 & $0.637-1.401$ & 0.776 & & & & 1.007 & $0.676-1.499$ & 0.973 & & & \\
\hline \multicolumn{13}{|l|}{ Necrosis } \\
\hline No & 1 & & & & & & 1 & & & & & \\
\hline Yes & 1.119 & $0.738-1.697$ & 0.597 & & & & 1.118 & $0.728-1.717$ & 0.611 & & & \\
\hline \multicolumn{13}{|l|}{ Differentiation } \\
\hline Well/Moderate & 1 & & & 1 & & & 1 & & & 1 & & \\
\hline Poor & 1.288 & $0.885-1.873$ & 0.186 & 1.029 & $0.698-1.517$ & 0.886 & 1.176 & $0.799-1.732$ & 0.410 & 0.873 & $0.582-1.311$ & 0.513 \\
\hline \multicolumn{13}{|l|}{ Invasion depth } \\
\hline $\mathrm{I}+\mathrm{II}$ & 1 & & & 1 & & & 1 & & & 1 & & \\
\hline III & 0.987 & $0.637-1.527$ & 0.952 & 1.560 & $0.933-2.609$ & 0.090 & 1.073 & $0.691-1.666$ & 0.753 & 1.686 & $0.996-2.855$ & 0.052 \\
\hline \multicolumn{13}{|l|}{ Lymph node metastasis } \\
\hline No & 1 & & & 1 & & & 1 & & & 1 & & \\
\hline Yes & 2.474 & $1.649-3.711$ & $<0.001 *$ & 2.469 & $1.565-3.895$ & $<0.001^{*}$ & 2.694 & $1.790-4.057$ & $<0.001^{*}$ & 2.899 & $1.824-4.606$ & $<0.001 *$ \\
\hline \multicolumn{13}{|l|}{ Distant metastasis } \\
\hline No & 1 & & & 1 & & & 1 & & & 1 & & \\
\hline Yes & 6.275 & $3.996-9.854$ & $<0.001^{*}$ & 6.131 & $3.769-9.971$ & $<0.001^{*}$ & 6.162 & $3.911-9.708$ & $<0.001 *$ & 6.389 & $\begin{array}{l}3.884- \\
10.509\end{array}$ & $<0.001^{*}$ \\
\hline \multicolumn{13}{|l|}{ Vessel involvement } \\
\hline No & 1 & & & 1 & & & 1 & & & 1 & & \\
\hline Yes & 1.159 & $0.674-1.995$ & 0.594 & 0.825 & $0.474-1.436$ & 0.497 & 1.133 & $0.647-1.985$ & 0.662 & 0.812 & $0.459-1.438$ & 0.475 \\
\hline \multicolumn{13}{|l|}{ Nerve involvement } \\
\hline No & 1 & & & 1 & & & 1 & & & 1 & & \\
\hline Yes & 1.046 & $0.686-1.593$ & 0.835 & 1.180 & $0.737-1.889$ & 0.491 & 1.172 & $0.767-1.791$ & 0.464 & 1.396 & $0.862-2.261$ & 0.175 \\
\hline \multicolumn{13}{|l|}{ FGFR1 amplification } \\
\hline $\begin{array}{l}\text { Disomy/Low } \\
\text { amplification }\end{array}$ & 1 & & & 1 & & & 1 & & & 1 & & \\
\hline High amplification & 2.001 & $1.099-3.644$ & $0.023^{*}$ & 1.646 & $0.900-3.008$ & 0.106 & 1.933 & $1.035-3.610$ & $0.039^{*}$ & 1.544 & $0.823-2.896$ & 0.176 \\
\hline
\end{tabular}

Invasive depth I, tumors had invaded to the mucous layer or submucosa; II, to the muscularis propria; III, to or beyond the adventitia.

$\mathrm{CI}$, confidence interval; HR, hazard ratio. ${ }^{*} \mathrm{P}<0.05$ indicated that the $95 \% \mathrm{CI}$ of HR was not including 1 . 
and $92.59 \pm 1.49$ months for patients with $F G F R 1^{\text {high }}$ and FGFR $1^{\text {low/disomy }}$ tumors in DFS $\geq 30$ months group $(P=0.007$, Figure $3 \mathrm{~L})$. No matter concerning to DFS or OS, there is no difference between FGFR $1^{\text {high }}$ and FGFR $1^{\text {low/disomy }}$ in DFS $<30$ months group (Figure 3I and 3J).

The univariate analysis revealed that patients with FGFR $1^{\text {high }}$ had a significantly adverse DFS and OS rate (DFS, $P=0.013$; OS, $P=0.010$ ) than patients with $F G F R 1^{\text {low/disomy }}$ in $\mathrm{DFS} \geq 30$ months group other than in DFS $<30$ months group (Table 4 and Supplementary Table 4). In addition, both DFS and OS were significantly associated with lymph node metastasis $(P<0.001)$, distant metastasis $(P<0.001)$, and vessel involvement $(P<0.001)$ in DFS $\geq 30$ months group (Table 4). However, the multivariate analysis revealed that a FGFR $1^{\text {high }}$ is not a significant independent adverse factor for DFS and OS in DFS $<30$ months group and DFS $\geq 30$ months group (Table 4 and Supplementary Table 4).

\section{Survival outcomes based on clinical stage and DFS time}

We combined the clinical stage and DFS 30-month to divide the whole cohort of ESCC patients into 4 groups. To the subset of patients whose DFS $\geq 30$ months in stage I-II, FGFR $1^{\text {high }}$ showed a significant adverse influence to both DFS and OS $(P=0.002$ and $P=0.003$, Figure $4 \mathrm{~B}$ and $4 \mathrm{~F})$. And there was no difference between FGFR $1^{\text {high }}$ and FGFR $1^{\text {low/disomy }}$ groups in other three subsets (Figure 4A, 4C-4E, 4G-4H).

To the subset of patients whose DFS time $\geq 30$ months in stage I-II, the results of the univariate analysis revealed that FGFR $1^{\text {high }}$ group had a significantly shorter DFS and OS time (DFS, $P=0.006$; OS, $P=0.003$ ) than patients with FGFR $1^{\text {low/disomy }}$ (Table 5). In addition, both DFS and OS were significantly associated with lymph node metastasis (DFS, $P=0.002$; OS, $P=0.001$ ) and distant metastasis $(P<0.001$, Table 5$)$. The multivariate analysis showed that $F G F R 1^{\text {high }}$ was significantly associated with a shorter OS $(P=0.037$, Table 5). However, there was no trend toward worse DFS for $F G F R l^{\text {high }}$ comparing to $F G F R 1^{\text {low/disomy }}$ in multivariate analysis $(P=0.123$, Table 5)

\section{DISCUSSION}

The poor prognosis of ESCC highlights the need for new prognostic markers in this disease and an improved understanding of the key genetic and progression are critical for the development of effective therapeutics.

In the present study, we investigated whether high FGFR1 amplification was associated with the clinicopathological parameters and its impact on survival in patients with operable ESCC. Our study demonstrated that high FGFR1 amplification is not a common genetic alteration $(8.7 \%)$ but presented as a delayed adverse prognostic factor in resected stage I-II ESCC patients. To the best of our knowledge, this is the first report analyzing the prognosis impact of FGFR1 amplification by linking it to clinical stage and DFS time. This information could have clinical value in identifying ESCC patients who are at high risk of progression and may benefit the most from FGFR-inhibiting drugs.

The prevalence of FGFR1 amplification is the firstly determining factor in judging whether FGFR inhibitors could be used in ESCC patients. Different from a singular criterion only using FGFR1 copy numbers, we chose a more sophisticated FGFRl FISH criterion considering gene copy number per nucleus, $F G F R 1 / \mathrm{CEN} 8$ ratio, and percentage of gene clusters at the same time [30]. Among those patients, $8.7 \%$ were high FGFRl amplification, $3.6 \%$ were low FGFR1 amplification, and $87.7 \%$ were disomy. The FGFR1 amplification rate $(12.3 \%)$ of our study, as determined by FISH analysis, was comparable to previous reports, ranging from $6 \%$ to $9.7 \%$ [27-29]. Given the relatively specific FGFR1 amplification, it may represent a potential therapeutic target for ESCC.

Recently, genome-wide comprehensive analysis found considerable overlap between the genes that are frequently mutated in ESCC and other types of squamous cell carcinoma [6, 7]. FGFR1 amplification has been reported in numerous kinds of tumors, especially in squamous cell lung cancer $[13,20]$ and head and neck squamous cell carcinoma [22]. However, when considering the prognostic value of FGFR1 amplification, the results are controversial. In resected squamous cell lung cancer, one study found that no significant difference in OS by FGFR1 amplification status no matter in the whole research group or in advanced stage subset [31]. In another study, FGFR1 amplification is an independent negative prognostic factor in surgically resected squamous cell lung cancer [19]. And the prognostic value is not consistent in ESCC between different groups as whether high FGFR1 amplification is an independent poor prognostic factor or no association between FGFR1 amplification status and clinical outcome $[27,28]$. This is may be due to different races and different criteria.

In our study, we evaluate the estimated mean DFS times and OS times in three FGFR1 groups (high amplification, low FGFRl amplification and disomy), and the DFS and OS time has no significant difference which is consistent with Kim's report [27]. Due to the similar survival outcome between low and no FGFR1 amplification group, we categorized total patients into FGFR $1^{\text {high }}$ group and FGFR $1^{\text {low/disomy }}$ group and assessed the survival outcomes of these two groups. FGFR $1^{\text {high }}$ did not represent a statistically significant adverse prognosis, which is different from the previous report [27], and this is may be owing to the tumor heterogeneity of different research groups from different countries.

As clinical stage is an important clinicopathological feature, the prognosis usually vary in patients with different stages. To squamous cell lung cancer, the FGFRl 
Table 4: Association between clinicopathological characteristics and DFS/OS by COX regression model analysis in ESCC patients with DFS $\geq 30$ months.

\begin{tabular}{|c|c|c|c|c|c|c|c|c|c|c|c|c|}
\hline & \multicolumn{6}{|c|}{ DFS } & \multicolumn{6}{|c|}{ os } \\
\hline & \multicolumn{3}{|c|}{ Univariate } & \multicolumn{3}{|c|}{ Multivariate } & \multicolumn{3}{|c|}{ Univariate } & \multicolumn{3}{|c|}{ Multivariate } \\
\hline & HR & CI $(95 \%)$ & Pvalue & HR & CI (95\%) & P value & HR & CI (95\%) & Pvalue & HR & CI $(95 \%)$ & Pvalue \\
\hline \multicolumn{13}{|l|}{ Gender } \\
\hline Male & 1 & & & 1 & & & 1 & & & 1 & & \\
\hline Female & 1.352 & $0.682-2.683$ & 0.388 & 1.664 & $0.818-3.384$ & 0.160 & 1.308 & $0.641-2.668$ & 0.461 & 1.626 & $0.776-3.404$ & 0.198 \\
\hline \multicolumn{13}{|l|}{ Age } \\
\hline$<60$ & 1 & & & & & & 1 & & & & & \\
\hline$\geq 60$ & 0.965 & $0.530-1.758$ & 0.908 & & & & 0.891 & $0.483-1.645$ & 0.713 & & & \\
\hline \multicolumn{13}{|l|}{ Tumor site } \\
\hline Upper/middle & 1 & & & & & & 1 & & & & & \\
\hline Low & 1.072 & $0.589-1.953$ & 0.820 & & & & 1.114 & $0.603-2.058$ & 0.731 & & & \\
\hline \multicolumn{13}{|l|}{ Smoking } \\
\hline No & 1 & & & & & & 1 & & & & & \\
\hline Yes & 0.974 & $0.520-1.823$ & 0.934 & & & & 1.153 & $0.615-2.159$ & 0.657 & & & \\
\hline \multicolumn{13}{|l|}{ Necrosis } \\
\hline No & 1 & & & & & & 1 & & & & & \\
\hline Yes & 1.261 & $0.657-2.423$ & 0.486 & & & & 1.434 & $0.742-2.772$ & 0.284 & & & \\
\hline \multicolumn{13}{|l|}{ Differentiation } \\
\hline Well/Moderate & 1 & & & 1 & & & 1 & & & 1 & & \\
\hline Poor & 1.701 & $0.935-3.093$ & 0.082 & 1.014 & $0.521-1.972$ & 0.968 & 1.857 & $1.006-3.427$ & $0.048^{*}$ & 1.021 & $0.514-2.028$ & 0.953 \\
\hline \multicolumn{13}{|l|}{ Clinical stage } \\
\hline I+II & 1 & & & 1 & & & 1 & & & 1 & & \\
\hline III & 2.563 & $1.390-4.726$ & $0.003^{*}$ & 0.428 & $0.142-1.292$ & 0.132 & 2.739 & $1.471-5.100$ & $0.001 *$ & 0.529 & $0.178-1.574$ & 0.253 \\
\hline \multicolumn{13}{|l|}{ Invasion depth } \\
\hline $\mathrm{I}+\mathrm{II}$ & 1 & & & 1 & & & 1 & & & 1 & & \\
\hline III+IV & 1.031 & $0.545-1.953$ & 0.925 & 1.148 & $0.471-2.802$ & 0.761 & 0.928 & $0.480-1.792$ & 0.823 & 0.814 & $0.320-2.071$ & 0.665 \\
\hline \multicolumn{13}{|l|}{$\begin{array}{l}\text { Lymph node } \\
\text { metastasis }\end{array}$} \\
\hline No & 1 & & & 1 & & & 1 & & & 1 & & \\
\hline Yes & 3.109 & $1.702-5.678$ & $<0.001^{*}$ & 3.304 & $1.293-8.441$ & $0.013^{*}$ & 3.400 & $1.826-6.331$ & $<0.001^{*}$ & 3.053 & $1.193-7.815$ & $0.020^{*}$ \\
\hline \multicolumn{13}{|l|}{ Distant metastasis } \\
\hline No & 1 & & & 1 & & & 1 & & & 1 & & \\
\hline Yes & 12.682 & $\begin{array}{l}6.145- \\
26.174\end{array}$ & $<0.001^{*}$ & 11.347 & $4.390-29.329$ & $<0.001 *$ & 10.692 & $\begin{array}{l}5.166- \\
22.127\end{array}$ & $<0.001^{*}$ & 7.802 & $3.077-19.781$ & $<0.001^{*}$ \\
\hline \multicolumn{13}{|l|}{$\begin{array}{l}\text { Vessel } \\
\text { involvement }\end{array}$} \\
\hline No & 1 & & & 1 & & & 1 & & & 1 & & \\
\hline Yes & 3.088 & $1.675-5.693$ & $<0.001^{*}$ & 1.999 & $0.973-4.107$ & 0.059 & 3.559 & $1.919-6.599$ & $<0.001^{*}$ & 2.389 & $1.157-4.934$ & $0.019^{*}$ \\
\hline \multicolumn{13}{|l|}{ Nerve involvement } \\
\hline No & 1 & & & 1 & & & 1 & & & 1 & & \\
\hline Yes & 1.221 & $0.645-2.312$ & 0.540 & 1.393 & $0.638-3.044$ & 0.405 & 1.306 & $0.685-2.490$ & 0.418 & 1.627 & $0.721-3.670$ & $\begin{array}{c}0.241 \\
\text { Continued) }\end{array}$ \\
\hline
\end{tabular}




\begin{tabular}{|c|c|c|c|c|c|c|c|c|c|c|c|c|}
\hline & \multicolumn{6}{|c|}{ DFS } & \multicolumn{6}{|c|}{ OS } \\
\hline & \multicolumn{3}{|c|}{ Univariate } & \multicolumn{3}{|c|}{ Multivariate } & \multicolumn{3}{|c|}{ Univariate } & \multicolumn{3}{|c|}{ Multivariate } \\
\hline & HR & CI (95\%) & $P$ value & HR & CI (95\%) & P value & HR & CI (95\%) & P value & HR & CI (95\%) & Pvalue \\
\hline \multicolumn{13}{|l|}{$\begin{array}{l}\text { FGFR1 } \\
\text { amplification }\end{array}$} \\
\hline $\begin{array}{l}\text { Disomy/Low } \\
\text { amplification }\end{array}$ & 1 & & & 1 & & & 1 & & & 1 & & \\
\hline $\begin{array}{l}\text { High } \\
\text { amplification }\end{array}$ & 2.789 & $1.239-6.276$ & $0.013^{*}$ & 1.490 & $0.614-3.620$ & 0.378 & 2.896 & $1.283-6.536$ & $0.010^{*}$ & 1.515 & $0.620-3.705$ & 0.362 \\
\hline
\end{tabular}

Invasive depth I, tumors had invaded to the mucous layer or submucosa; II, to the muscularis propria; III, to or beyond the adventitia. CI, confidence interval; HR, hazard ratio. ${ }^{*} \mathrm{P}<0.05$ indicated that the $95 \% \mathrm{CI}$ of HR was not including 1 .

amplification is an independent adverse prognostic marker in early stage patients [32], and another study found that no significant difference in OS by FGFR1 amplification status in advanced stage subset [31]. We then categorized the patients into stage I-II group and stage III-IV group. To the stage I-II group, the estimated mean DFS and OS time of the FGFR $I^{\text {high }}$ group was significantly shorter compared with that of the FGFR $1^{\text {low/disomy }}$ group. Interesting, the trend is only can be detected in stage I-II group other than stage III-IV group, implying that high FGFRl amplification prognostic value is relying on clinical stage. The result is confirmed by univariate $\mathrm{COX}$ regression analysis.

DFS time is measured from the time of surgery to initial tumor relapse (local recurrence or distant) or death as a result of any cause and is an important index for surgeon to follow up. Moreover, DFS is also served as the endpoint of the phase III clinical trials of antitumor drugs. When we divided the whole group into two subsets according to the DFS time (30-month), the estimated mean DFS and OS time of the FGFR $1^{\text {high }}$ patients was significantly shorter compared with that of the FGFR $1^{\text {low }}$
${ }^{\text {disomy }}$ patients in DFS $\geq 30$ months group. Clearly, after the patient finished radical operation, if the patient can live without recurrence or distant metastasis for more than 30 months, the FGFR $I^{\text {high }}$ status is important to the prognosis of the patient, indicating that high FGFR1 amplification is a delayed prognostic factor which is just as same as the prognostic value of EGFR amplification in ESCC [33].

Aimed to find the most influenced subgroup patients by FGFR $1^{\text {high }}$ status, we firstly combined the clinical stage and DFS 30-month to divide the whole cohort of ESCC patients. To the subset of patients whose DFS $\geq 30$ months in stage I-II, FGFR $1^{\text {high }}$ showed a significant adverse influence to both DFS and OS. And there is no difference between FGFR $1^{\text {high }}$ and FGFR $1^{\text {low/disomy }}$ groups in other three subsets. By this way, we precisely selected the most influenced patients by FGFR $1^{\text {high }}$ status.

FGFR1 amplification is one of the most promising findings in ESCC due to the availability of FGFR inhibitors' application. Several small molecules, such AZD4547 and PD173073, targeting the FGFR1 tyrosine kinase are now in clinical trials for the treatment of
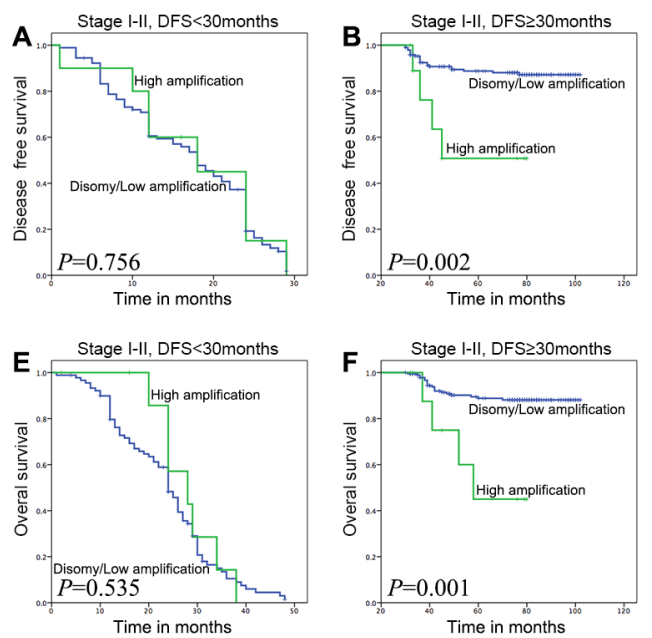
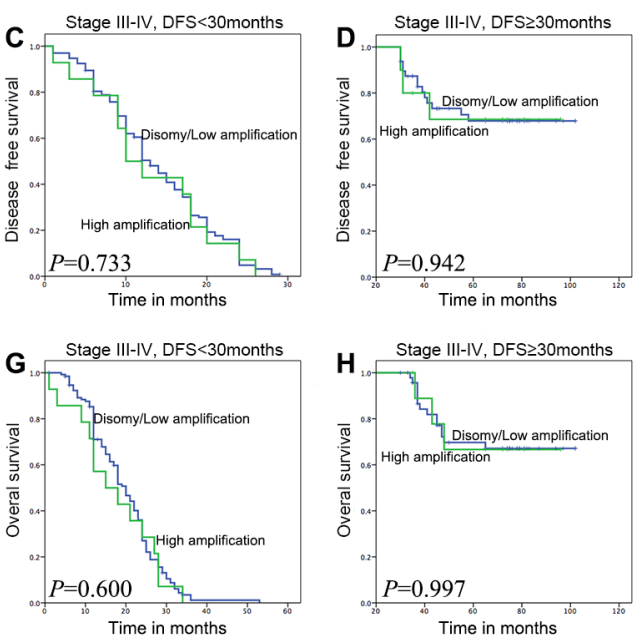

Figure 4: Survival analyses based on clinical stage and DFS time 30 months of ESCC patients. In stage I-II patients with DFS time $\geq 30$ months, high FGFRl amplification was associated with adverse DFS and OS (B and F; $P=0.002$ or 0.001 ), but not in other three groups which are stage I-II with DFS $<30$ months, stage III-IV with DFS $<30$ months, and stage III-IV with DFS $\geq 30$ months (DFS: A, C and $\mathbf{D} ; P=0.756,0.733$ or 0.942 ; OS: $\mathbf{E}, \mathbf{G}$ and $\mathbf{H} ; P=0.535,0.600$ or 0.997 ). 
Table 5: Association between clinicopathological characteristics and DFS/OS by COX regression model analysis in ESCC patients with DFS $\geq \mathbf{3 0}$ months in stage I and II.

\begin{tabular}{|c|c|c|c|c|c|c|c|c|c|c|c|c|}
\hline & \multicolumn{6}{|c|}{ DFS } & \multicolumn{6}{|c|}{ OS } \\
\hline & \multicolumn{3}{|c|}{ Univariate } & \multicolumn{3}{|c|}{ Multivariate } & \multicolumn{3}{|c|}{ Univariate } & \multicolumn{3}{|c|}{ Multivariate } \\
\hline & HR & CI $(95 \%)$ & P value & HR & CI $(95 \%)$ & P value & HR & CI $(95 \%)$ & P value & HR & CI $(95 \%)$ & P value \\
\hline \multicolumn{13}{|l|}{ Gender } \\
\hline Male & 1 & & & 1 & & & 1 & & & 1 & & \\
\hline Female & 1.536 & $0.668-3.533$ & 0.313 & 2.498 & $1.017-6.136$ & $0.046^{*}$ & 1.795 & $0.768-4.194$ & 0.177 & 2.859 & $1.131-7.227$ & $0.026^{*}$ \\
\hline \multicolumn{13}{|l|}{ Age } \\
\hline$<60$ & 1 & & & & & & 1 & & & & & \\
\hline$\geq 60$ & 0.663 & $0.307-1.434$ & 0.297 & & & & 0.559 & $0.248-1.259$ & 0.161 & & & \\
\hline \multicolumn{13}{|l|}{ Tumor site } \\
\hline Upper/middle & 1 & & & & & & 1 & & & & & \\
\hline Low & 0.830 & $0.370-1.864$ & 0.653 & & & & 0.833 & $0.356-1.947$ & 0.673 & & & \\
\hline \multicolumn{13}{|l|}{ Smoking } \\
\hline No & 1 & & & & & & 1 & & & & & \\
\hline Yes & 0.637 & $0.256-1.587$ & 0.333 & & & & 0.688 & $0.273-1.732$ & 0.427 & & & \\
\hline \multicolumn{13}{|l|}{ Necrosis } \\
\hline No & 1 & & & & & & 1 & & & & & \\
\hline Yes & 0.840 & $0.316-2.231$ & 0.726 & & & & 0.989 & $0.369-2.653$ & 0.983 & & & \\
\hline \multicolumn{13}{|l|}{ Differentiation } \\
\hline Well/Moderate & 1 & & & 1 & & & 1 & & & 1 & & \\
\hline Poor & 1.345 & $0.610-2.965$ & 0.462 & 1.032 & $0.442-2.409$ & 0.942 & 1.273 & 0.557-2.909 & 0.567 & 0.785 & $0.304-1.888$ & 0.552 \\
\hline \multicolumn{13}{|l|}{ Invasion depth } \\
\hline $\mathrm{I}+\mathrm{II}$ & 1 & & & 1 & & & 1 & & & 1 & & \\
\hline III & 0.784 & $0.295-2.081$ & 0.625 & 1.080 & $0.313-3.728$ & 0.904 & 0.819 & $0.306-2.194$ & 0.691 & 0.885 & $0.242-3.234$ & 0.854 \\
\hline \multicolumn{13}{|l|}{$\begin{array}{l}\text { Lymph node } \\
\text { metastasis }\end{array}$} \\
\hline No & 1 & & & 1 & & & 1 & & & 1 & & \\
\hline Yes & 3.635 & $1.580-8.366$ & $0.002 *$ & 5.211 & $1.896-14.317$ & $0.001^{*}$ & 4.021 & $1.720-9.401$ & $0.001 *$ & 5.164 & $1.878-14.195$ & $0.001 *$ \\
\hline \multicolumn{13}{|l|}{ Distant metastasis } \\
\hline No & 1 & & & 1 & & & 1 & & & 1 & & \\
\hline Yes & 19.124 & $7.023-52.075$ & $<0.001^{*}$ & 30.942 & $9.189-104.191$ & $<0.001^{*}$ & 14.484 & $5.255-39.919$ & $<0.001^{*}$ & 20.623 & $6.180-68.817$ & $<0.001 *$ \\
\hline \multicolumn{13}{|l|}{$\begin{array}{l}\text { Vessel } \\
\text { involvement }\end{array}$} \\
\hline No & 1 & & & 1 & & & 1 & & & 1 & & \\
\hline Yes & 2.432 & $0.976-6.059$ & 0.056 & 2.154 & $0.777-5.973$ & 0.140 & 2.608 & $1.035-6.547$ & $0.042 *$ & 2.343 & $0.863-6.363$ & 0.095 \\
\hline \multicolumn{13}{|l|}{$\begin{array}{l}\text { Nerve } \\
\text { involvement }\end{array}$} \\
\hline No & 1 & & & 1 & & & 1 & & & 1 & & \\
\hline Yes & 1.234 & $0.518-2.938$ & 0.635 & 1.885 & $0.629-5.646$ & 0.258 & 1.424 & $0.590-3.435$ & 0.431 & 2.653 & $0.823-8.557$ & 0.102 \\
\hline \multicolumn{13}{|l|}{$\begin{array}{l}\text { FGFR1 } \\
\text { amplification }\end{array}$} \\
\hline $\begin{array}{l}\text { Disomy/Low } \\
\text { amplification }\end{array}$ & 1 & & & 1 & & & 1 & & & 1 & & \\
\hline $\begin{array}{l}\text { High } \\
\text { amplification }\end{array}$ & 4.521 & $1.549-13.195$ & $0.006^{*}$ & 2.430 & $0.786-7.514$ & 0.123 & 5.180 & $1.766-15.194$ & $0.003 *$ & 3.239 & $1.076-9.746$ & $0.037^{*}$ \\
\hline
\end{tabular}

Invasive depth I, tumors had invaded to the mucous layer or submucosa; II, to the muscularis propria; III, to or beyond the adventitia.

CI, confidence interval; HR, hazard ratio. " $\mathrm{P}<0.05$ indicated that the $95 \% \mathrm{CI}$ of HR was not including 1 . 
patients with squamous cell lung cancer and other solid malignant tumors $[13,34]$. And FGFR1 amplification is the most important inclusion criterion. Our study precisely stratified the patients according to clinical stage and DFS time, finding out the subgroup patients whose prognosis were most decreased by high FGFR1 amplification and this may be important in the future for selecting patients enrolled in clinical trials, providing a theoretical basis in patient selection.

In conclusion, we demonstrated that FGFRI amplification was an infrequent genetic alteration, and for firstly, we found high FGFR1 amplification was an independent delayed adverse prognostic factor only in stage I-II ESCC patients, suggesting that FGFR amplification may be a viable prognostic factor in these patients.

\section{MATERIALS AND METHODS}

\section{Patients and tissue samples}

The study was conducted in a cohort of patients with ESCC who underwent surgical resection in our institution from 2007 to 2010. Two pathologists confirmed the diagnosis of ESCC by hematoxylin-eosin (HE) staining. A predesigned data collection format was used to review the patients' medical records for evaluation of clinicopathological characteristics and survival outcomes. We identified 592 patients. Of those we excluded patients with very limited tumor tissue, patients with neoadjuvant therapy, and patients with incomplete clinicopathological information or survival information $(n=49)$. Paraffinembedded (FFPE) tumor specimens were used to construct a tissue microarray (TMA) [35] and then performed HE staining to estimate the tumor ratio of each core. A total of 37 patients were excluded because of limited tumor tissue (less than 100 tumor nuclei) in TMA (Figure 1, Table 1). Eventually, the tumor samples of 506 patients were available for examination of FGFR1 amplification. Each patient provided informed consent for the use of their tissue samples and the study was approved by the institutional review board of Zhongshan Hospital.

\section{FGFR1 fluorescence in situ hybridization}

Fluorescent in situ hybridization (FISH) assay was performed on the tissue microarrays by using FGFR1 probe that hybridizes to the band 8 p12 with Spectrum Red and CEP 8 with SpectrumAqua Probe RUO (green) (Abbott Molecular, Abbott Park, IL) following routine methods. Two experienced evaluators blinded to the clinical data interpreted FISH analyses. At least 100 nuclei per patient were evaluated. The prespecified threshold for assigning a sample to the FGFR $1^{\text {high }}$ group was an $F G F R 1 / C E N 8$ ratio is $\geq 2$. 0 , or average number of FGFR1 signals/ tumor cell nucleus $\geq 6.0$, or percentage of tumor cells containing $\geq 15$ FGFRl signals or large cluster in $\geq 10 \%$. Percentage of tumor cells containing $\geq 5$ FGFR1 signals in $\geq 50 \%$ was defined as low amplification, and a copy number of two was considered disomy [30].

\section{Statistical analysis}

The primary end point was to assess whether FGFR1 amplification affected survival in terms of DFS and OS in patients with resected ESCC. DFS was measured from the time of surgery to initial tumor relapse (local recurrence or distant) or death as a result of any cause. OS, calculated from the time of surgery to death or last follow-up date. Associations with clinical characteristics were evaluated by using Fisher's exact test or the $\chi^{2}$ test. Kaplan-Meier curves with log-rank tests were used to calculate the cumulative survival proportion for OS and DFS by FGFR1 amplification level. A Cox proportional hazards model was applied to investigate the univariate and multivariate hazard ratios for the study variables. Multivariate analysis was performed for all the significant variables in the univariate analysis. Statistical significance was set at $P<0.05$ for all analyses. All statistical analyses were performed by using SPSS version 22.0 (SPSS, Chicago, IL).

\section{ACKNOWLEDGMENTS}

We gratefully acknowledge the support of the patients and their families who agreed to contribute to this research program.

\section{CONFLICTS OF INTEREST}

The authors have no conflicts of interest to declare.

\section{GRANT SUPPORT}

This work was supported by Shanghai Municipal Commission of Health and Family Planning, Keydeveloping disciplines (No.2015ZB0201)

\section{REFERENCES}

1. Jemal A, Bray F, Center MM, Ferlay J, Ward E, Forman D. Global cancer statistics. CA Cancer J Clin. 2011; 61: 69-90. https://doi.org/10.3322/caac.20107.

2. Arnold M, Soerjomataram I, Ferlay J, Forman D. Global incidence of oesophageal cancer by histological subtype in 2012. Gut. 2015; 64: 381-7. https://doi.org/10.1136/ gutjnl-2014-308124.

3. Rustgi AK, El-Serag HB. Esophageal carcinoma. N Engl J Med. 2014; 371: 2499-509. https://doi.org/10.1056/ NEJMra1314530. 
4. Chen W, Zheng R, Baade PD, Zhang S, Zeng H, Bray F, Jemal A, Yu XQ, He J. Cancer statistics in China, 2015. CA Cancer J Clin. 2016; 66: 115-32. https://doi.org/10.3322/ caac. 21338

5. Song Y, Li L, Ou Y, Gao Z, Li E, Li X, Zhang W, Wang J, Xu L, Zhou Y, Ma X, Liu L, Zhao Z, et al. Identification of genomic alterations in oesophageal squamous cell cancer. Nature. 2014; 509: 91-5. https://doi.org/10.1038/ nature13176.

6. Lin DC, Hao JJ, Nagata Y, Xu L, Shang L, Meng X, Sato Y, Okuno Y, Varela AM, Ding LW, Garg M, Liu LZ, Yang H, et al. Genomic and molecular characterization of esophageal squamous cell carcinoma. Nat Genet. 2014; 46: 467-73. https://doi.org/10.1038/ng.2935.

7. Gao YB, Chen ZL, Li JG, Hu XD, Shi XJ, Sun ZM, Zhang F, Zhao ZR, Li ZT, Liu ZY, Zhao YD, Sun J, Zhou CC, et al. Genetic landscape of esophageal squamous cell carcinoma. Nat Genet. 2014; 46: 1097-102. https://doi.org/10.1038/ ng.3076.

8. Zhang L, Zhou Y, Cheng C, Cui H, Cheng L, Kong P, Wang J, Li Y, Chen W, Song B, Wang F, Jia Z, Li L, et al. Genomic analyses reveal mutational signatures and frequently altered genes in esophageal squamous cell carcinoma. Am J Hum Genet. 2015; 96: 597-611. https:// doi.org/10.1016/j.ajhg.2015.02.017.

9. Sawada G, Niida A, Uchi R, Hirata H, Shimamura T, Suzuki Y, Shiraishi Y, Chiba K, Imoto S, Takahashi Y, Iwaya T, Sudo T, Hayashi T, et al. Genomic Landscape of Esophageal Squamous Cell Carcinoma in a Japanese Population. Gastroenterology. 2016; 150: 1171-82. https:// doi.org/10.1053/j.gastro.2016.01.035.

10. Bang YJ, Van Cutsem E, Feyereislova A, Chung HC, Shen L, Sawaki A, Lordick F, Ohtsu A, Omuro Y, Satoh T, Aprile G, Kulikov E, Hill J, et al. Trastuzumab in combination with chemotherapy versus chemotherapy alone for treatment of HER2-positive advanced gastric or gastro-oesophageal junction cancer (ToGA): a phase 3, open-label, randomised controlled trial. Lancet. 2010; 376: 687-97. https://doi. org/10.1016/S0140-6736(10)61121-X.

11. Reichelt U, Duesedau P, Tsourlakis M, Quaas A, Link BC, Schurr PG, Kaifi JT, Gros SJ, Yekebas EF, Marx A, Simon R, Izbicki JR, Sauter G. Frequent homogeneous HER-2 amplification in primary and metastatic adenocarcinoma of the esophagus. Mod Pathol. 2007; 20: 120-9. https://doi. org/10.1038/modpathol.3800712.

12. Chin K, DeVries S, Fridlyand J, Spellman PT, Roydasgupta R, Kuo WL, Lapuk A, Neve RM, Qian Z, Ryder T, Chen F, Feiler H, Tokuyasu T, et al. Genomic and transcriptional aberrations linked to breast cancer pathophysiologies. Cancer Cell. 2006; 10: 529-41. https://doi.org/10.1016/j. ccr.2006.10.009.

13. Weiss J, Sos ML, Seidel D, Peifer M, Zander T, Heuckmann JM, Ullrich RT, Menon R, Maier S, Soltermann A, Moch H, Wagener P, Fischer F, et al. Frequent and focal FGFR1 amplification associates with therapeutically tractable
FGFR1 dependency in squamous cell lung cancer. Sci Transl Med. 2010; 2: 62ra93. https://doi.org/10.1126/ scitranslmed.3001451.

14. Hubbard SR, Till JH. Protein tyrosine kinase structure and function. Annu Rev Biochem. 2000; 69: 373-98. https://doi. org/10.1146/annurev.biochem.69.1.373.

15. Babina IS, Turner NC. Advances and challenges in targeting FGFR signalling in cancer. Nat Rev Cancer. 2017. https:// doi.org/10.1038/nrc.2017.8.

16. Eswarakumar VP, Lax I, Schlessinger J. Cellular signaling by fibroblast growth factor receptors. Cytokine Growth Factor Rev. 2005; 16: 139-49. https://doi.org/10.1016/j. cytogfr.2005.01.001.

17. Grose R, Dickson C. Fibroblast growth factor signaling in tumorigenesis. Cytokine Growth Factor Rev. 2005; 16: 17986. https://doi.org/10.1016/j.cytogfr.2005.01.003.

18. Helsten T, Elkin S, Arthur E, Tomson BN, Carter J, Kurzrock R. The FGFR Landscape in Cancer: Analysis of 4,853 Tumors by Next-Generation Sequencing. Clin Cancer Res. 2016; 22: 259-67. https://doi.org/10.1158/1078-0432. CCR-14-3212.

19. Kim HR, Kim DJ, Kang DR, Lee JG, Lim SM, Lee CY, Rha SY, Bae MK, Lee YJ, Kim SH, Ha SJ, Soo RA, Chung KY, et al. Fibroblast growth factor receptor 1 gene amplification is associated with poor survival and cigarette smoking dosage in patients with resected squamous cell lung cancer. J Clin Oncol. 2013; 31: 731-7. https://doi.org/10.1200/ JCO.2012.43.8622.

20. Sousa V, Reis D, Silva M, Alarcao AM, Ladeirinha AF, d'Aguiar MJ, Ferreira T, Caramujo-Balseiro S, Carvalho L. Amplification of FGFR1 gene and expression of FGFR1 protein is found in different histological types of lung carcinoma. Virchows Arch. 2016; 469: 173-82. https://doi. org/10.1007/s00428-016-1954-5.

21. Brunello E, Brunelli M, Bogina G, Calio A, Manfrin E, Nottegar A, Vergine M, Molino A, Bria E, Massari F, Tortora G, Cingarlini S, Pedron S, et al. FGFR-1 amplification in metastatic lymph-nodal and haematogenous lobular breast carcinoma. J Exp Clin Cancer Res. 2012; 31 : 103. https://doi.org/10.1186/1756-9966-31-103.

22. von Massenhausen A, Franzen A, Heasley L, Perner S. FGFR1 as a novel prognostic and predictive biomarker in squamous cell cancers of the lung and the head and neck area. Ann Transl Med. 2013; 1: 23. https://doi.org/10.3978/j. issn.2305-5839.2013.06.08.

23. Freier K, Schwaenen C, Sticht C, Flechtenmacher C, Muhling J, Hofele C, Radlwimmer B, Lichter P, Joos S. Recurrent FGFR1 amplification and high FGFR1 protein expression in oral squamous cell carcinoma (OSCC). Oral Oncol. 2007; 43: 60-6. https://doi.org/10.1016/j. oraloncology.2006.01.005.

24. Zhou W, Du X, Song F, Zheng H, Chen K, Zhang W, Yang J. Prognostic roles for fibroblast growth factor receptor family members in malignant peripheral nerve sheath tumor. 
Oncotarget. 2016; 7: 22234-44. https://doi.org/10.18632/ oncotarget.8067.

25. Liu L, Ye TH, Han YP, Song H, Zhang YK, Xia Y, Wang NY, Xiong Y, Song XJ, Zhu YX, Li de L, Zeng J, Ran K, et al. Reductions in myeloid-derived suppressor cells and lung metastases using AZD4547 treatment of a metastatic murine breast tumor model. Cell Physiol Biochem. 2014; 33: 633 45. https://doi.org/10.1159/000358640.

26. Pearson A, Smyth E, Babina IS, Herrera-Abreu MT, Tarazona N, Peckitt C, Kilgour E, Smith NR, Geh C, Rooney C, Cutts R, Campbell J, Ning J, et al. High-Level Clonal FGFR Amplification and Response to FGFR Inhibition in a Translational Clinical Trial. Cancer Discov. 2016; 6: 838-51. https://doi.org/10.1158/2159-8290. CD-15-1246.

27. Kim HS, Lee SE, Bae YS, Kim DJ, Lee CG, Hur J, Chung H, Park JC, Jung DH, Shin SK, Lee SK, Lee YC, Kim HR, et al. Fibroblast growth factor receptor 1 gene amplification is associated with poor survival in patients with resected esophageal squamous cell carcinoma. Oncotarget. 2015; 6: 2562-72. https://doi.org/10.18632/oncotarget.2944.

28. von Loga K, Kohlhaussen J, Burkhardt L, Simon R, Steurer S, Burdak-Rothkamm S, Jacobsen F, Sauter G, Krech T. FGFR1 Amplification Is Often Homogeneous and Strongly Linked to the Squamous Cell Carcinoma Subtype in Esophageal Carcinoma. PLoS One. 2015; 10: e0141867. https://doi.org/10.1371/journal.pone.0141867.

29. Ishizuka T, Tanabe C, Sakamoto H, Aoyagi K, Maekawa M, Matsukura N, Tokunaga A, Tajiri T, Yoshida T, Terada M, Sasaki H. Gene amplification profiling of esophageal squamous cell carcinomas by DNA array CGH. Biochem Biophys Res Commun. 2002; 296: 152-5.
30. Schildhaus HU, Heukamp LC, Merkelbach-Bruse S, Riesner K, Schmitz K, Binot E, Paggen E, Albus K, Schulte W, Ko YD, Schlesinger A, Ansen S, Engel-Riedel W, et al. Definition of a fluorescence in-situ hybridization score identifies high- and low-level FGFR1 amplification types in squamous cell lung cancer. Mod Pathol. 2012; 25: 1473-80. https://doi.org/10.1038/modpathol.2012.102.

31. Heist RS, Mino-Kenudson M, Sequist LV, Tammireddy S, Morrissey L, Christiani DC, Engelman JA, Iafrate AJ. FGFR1 amplification in squamous cell carcinoma of the lung. J Thorac Oncol. 2012; 7: 1775-80. https://doi. org/10.1097/JTO.0b013e31826aed28.

32. Cihoric N, Savic S, Schneider S, Ackermann I, BichselNaef M, Schmid RA, Lardinois D, Gugger M, Bubendorf L, Zlobec I, Tapia C. Prognostic role of FGFR1 amplification in early-stage non-small cell lung cancer. Br J Cancer. 2014; 110: 2914-22. https://doi.org/10.1038/bjc.2014.229.

33. Jiang D, Li X, Wang H, Shi Y, Xu C, Lu S, Huang J, Xu Y, Zeng H, Su J, Hou Y, Tan L. The prognostic value of EGFR overexpression and amplification in Esophageal squamous cell Carcinoma. BMC Cancer. 2015; 15: 377. https://doi. org/10.1186/s12885-015-1393-8.

34. Zhang J, Zhang L, Su X, Li M, Xie L, Malchers F, Fan S, Yin X, Xu Y, Liu K, Dong Z, Zhu G, Qian Z, et al. Translating the therapeutic potential of AZD4547 in FGFR1-amplified non-small cell lung cancer through the use of patient-derived tumor xenograft models. Clin Cancer Res. 2012; 18: 665867. https://doi.org/10.1158/1078-0432.CCR-12-2694.

35. Shi Y, He D, Hou Y, Hu Q, Xu C, Liu Y, Jiang D, Su J, Zeng H, Tan Y. An alternative high output tissue microarray technique. Diagn Pathol. 2013; 8: 9. https://doi. org/10.1186/1746-1596-8-9. 